\title{
MEMPERSIAPKAN KEUANGAN DALAM MENGHADAP MASA PURNABAKTI
}

\author{
Ana Rusmardiana \\ Program Studi Informatika, Fakultas Teknik dan Ilmu Komputer \\ Universitas Indraprasta PGRI \\ Email: ana.irawan93@gmail.com
}

Diterima: Februari; Disetujui: April; dipublikasikan: 28 April 2019

\begin{abstract}
One of the retirement preparations is preparation in finance, financial planning is an effort that aims to achieve financial freedom in old age. This discussion describes the relevance of the human life cycle with financial planning in an effort to deal with retirement. To deal with retirement is not always with entrepreneurship skills but there are 5 (five) other factors that also influence it, namely: reorganizing finance, drafting a reserve fund by not spending all income earned, reviewing if necessary controlling debt-debt, buying insurance and investing. Intended to motivate workers early in preparing their finances in order to deal with their retirement later. Descriptive qualitative approach using the library method and interview method for a workshop company that is providing pre-retirement preparation training to some of its employees.
\end{abstract}

Keywords: retirement, human life cycle, financial planning

\begin{abstract}
ABSTRAK
Salah satu persiapan masa purnabakti adalah persiapan di bidang keuangan, perencanaan keuangan adalah sebagai usaha yang bertujuan untuk mencapai kebebasan finansial di masa tua. Pembahasan ini memaparkan keterkaitan siklus hidup manusia dengan perencanaan keuangan dalam upaya menghadapi masa purnabakti. Untuk menghadapi masa purnabakti tidak selalu dengan keterampilan berwirausaha saja namum ada 5(lima) faktor lainnya yang juga mempengaruhinya, yaitu: mengatur kembali keuangan, membuat konsep dana cadangan dengan tidak membelanjakan semua penghasilan yang diperoleh, meninjau kembali bila perlu kendalikan hutang-hutang, membeli asuransi dan berinvestasi. Dimaksudkan untuk memotivasi para pekerja lebih dini dalam mem-persiapkan keuangannya guna menghadapi masa purnabaktinya kelak. Pendekatan kualitatif deskriptif dengan menggunakan metode kepustakaan dan metode wawancara pada sebuah perusahaan perbengkelan yang tengah memberikan pelatihan persiapan masa pra-purnabakti kepada beberapa karyawannya.
\end{abstract}

Kata Kunci: Purnabakti, Siklus Hidup Manusia, Perencanaan Keuangan 


\section{PENDAHULUAN}

Secara alamiah maupun lahiriah memasuki usia purnabakti adalah suatu kondisi maupun situasi yang tidak dapat dihindari. Hal ini terjadi disebabkan oleh memasuki usia purnabakti, permintaan sendiri, ataupun bisa terjadi dikarenakan sakit yang berlarut-larut ataupun direkomendasikan. Purnabakti atau pensiun adalah seseorang yang sudah tidak bekerja lagi karena usianya sudah lanjut dan harus diberhentikan, ataupun atas permintaan sendiri (https://id.wikipedia.org/wiki/Pensiun). Purnabakti juga memiliki pengertian sebagai hak seseorang untuk memperoleh penghasilan setelah bekerja sekian tahun dan sudah memasuki usia pensiun atau disebabkan oleh lainnya sesuai dengan perjanjian yang telah ditetapkan. Biasanya peolehan penghasilan yang diberikan dalam bentuk uang, sementara besarannya tergantung dari peraturan yang telah ditetapkan (Martono,2016: 155). Purnabakti adalah masa seseorang akan mengalami penurunan penghasilan yang diterimanya dibandingkan semasa dia bekerja ,sementara biaya hidup yang dikeluarkan tetap sama atau lebih (Sundjaja et all , 2015:502).

Usia pensiun tiap negara di dunia berbeda beda, di Amerika Serikat usia pensiun ditetapkan menjadi 70(tujuhpuluh) tahun untuk perusahaan, industri, dan pemerintahan federal (Santrock,2015: 227), sedangkan di Indonesia terdapat kebijakan tersendiri dalam hal usia pensiun yang diatur dalam Peraturan Pemerintah maupun Undang-Undang yang secara umum berkisar antara 56 (limapuluh enam) tahun sampai dengan 79(tujuhpuluh) tahun. Adapun peraturan maupun UU di Indonesia berkaitan dengan batas usia purnabakti dapat dilihat pada:

1. Peraturan Pemerintah No.44 Tahun 2011 tentang Perubahan Ketiga Peraturan Pemerintah No.32 Tahun 1979. Pemberhentian Pegawai Negeri Sipil;

2. Peraturan Pemerintah No.45 Tahun 2015 tentang Penyelenggaraan Program Jaminan Pensiun;

3. Peraturan Pemerintah No.11 Tahun 2017 tentang Manajemen PNS;

4. Peraturan Mentri Pendidikan Nasional Tahun 2008 tentang Perpanjangan Batas Usia Pensiun Pegawai Negeri Sipil Yang Menduduki Jabatan Guru Besar/Professor Dan Pengangkatan Guru Besar/Professor Emeritus;

5. Peraturan Mentri Riset dan Teknologi No.2 Tahun 2016 tentang Perubahan Permenristekdikti No 26 Tahun 2015;

6. Undang-Undang Republik Indonesia No. 12 Tahun 2012 tentang Pendidikan Tingi;

Menurut Didin, Hafidhuddin dan Henri Tanjung (2015:77), perencanaan kuangan merupakan hal yang penting dalam mencapai suatu tujuan finansial, sedangkan menurut Financial Planning Standard Board(FPSB), perencanaan keuangan adalah proses untuk mencapai tujuan hidup seseorang melalui pengelolaan keuangan secara terintegrasi dan terencana. Yang termasuk dalam tujuan hidup seseorang, antara lain menyiapkan dana pendidikan bagi anak, menyiapkan dana hari tua bagi dirinya dan pasangan hidupnya, menyiapkan dana untuk memiliki rumah, menyiapkan warisan bagi keluarga tercinta dan lainlain (http://www.fpsbindonesia.net/index.php?menu=publik media \#definisi). Perencanaan keuangan sangat penting bagi siapa saja karena perencanaan keuangan berfungsi untuk menggerakan usaha dan mengukur pencapain sebagai pemberian tugas terutama untuk kehidupan seseorang, seperti halnya dalam mempersiapkan masa purnabakti.

Penelitian ini merupakan lanjutan dari penelitian sebelumnya dengan judul Komitmen PT GMF AeroAsia terhadap Karyawan Pra-Purnabakti melalui Pembekalan yang ditulis oleh peneliti sendiri pada jurnal SOSIO-E-KONS, Vol. 8 No. 3, Desember 2016. Untuk identifikasi dari pokok permasalahan dalam pembahasan ini adalah langkah-langkah yang harus dipersiapkan dalam masalah keuangan guna menghadapi dan menjalani masa purnabakti sehingga ketika berada dimasa purnabakti, kehidupannya dapat dinikmati dengan suka cita, sejahtera, bahagia dan tidaklah menjadi beban bagi siapapun. Sedangkan perumusan 
permasalahannya adalah: (1) Bagaimana siklus hidup manusia dikaitkan dengan perencanaan keuangan?, (2) Bagaimana untuk mempersiapkan keuangan dalam menghadapi masa purnabakti?

Harapan dan tujuan adalah menggugah dan memotivasi kepada para pekerja agar dapat mempersiapkan secara dini keuangannya dengan sebaik-baiknya guna menghadapi masa depan dan juga dalam menghadapi masa purnabakti. Diharapkan pula tetap memiliki semangat untuk tetap dapat beraktivitas guna mengisi kehidupan di masa purnabakti sehingga tetap memiliki arti dan warna kehidupan.

\section{METODE}

Pendekatan penelitian adalah kualitatif deskriptif yang berarti tipe penelitian yang tidak menggunakan metode statistik (Prasetyono, 2016). Metode yang digunakan adalah metode kepustakaan dan metode wawancara terhadap 14(empatbelas) peserta berikut pasangannya atau total 28(duapuluh delapan) peserta yang mengikuti training masa persiapan pra-purnabakti sebuah perusahaan perbengkelan di daerah Tangerang Jawa Barat, yang penyelenggaraannya dilakukan \pm selama 1(satu) minggu di sebuah hotel ternama di Bandung Jawa Barat. Dalam penyelenggaraan yang dilakukan perusahaan tersebut tidaklah membeda-bedakan jabatan ataupun posisi apakah direktur, manajer, satpam ataupun pesuruh, dengan kata lain semua karyawan adalah sama, yaitu karyawan-karyawan yang akan mencapai masa pra-purnabakti minimal 6(enam) tahun sebelum masa purnabakti.

Dalam penelitian kuantitatif, peneliti menggunakan metode analisis fenomenologi interpreatatif, yaitu pendekatan penelitian kualitatif yang berkomitmen untuk memeriksa orang memaknai pengalaman besar dalam hidup mereka. Analisis fenomenologi interpretatif adalah fenomenologis, dalam hal ini berkaitan dengan mengeksplorasi pengalaman dalam diri sendiri (Smith,2017). Beberapa penelitian yang relevan, antara lain:

\begin{tabular}{|c|c|c|}
\hline Peneliti & Judul & Hasil Penelitian \\
\hline Ana Rusmardiana & $\begin{array}{lr}\text { Komitmen } & \text { PT. } \\
\text { AeroAsia } & \text { TMF } \\
\text { Karyawan } & \text { Pra-Purnabakti } \\
\text { Melalui Pembekalan }\end{array}$ & $\begin{array}{l}\text { Perusahaan memberikan pembekalan } \\
\text { melalui pelatihan } \\
\text { memperkenalkan pilihan-pilihan hidup } \\
\text { ketika kelak pensiun. }\end{array}$ \\
\hline $\begin{array}{l}\text { Navickas M, Tadas } \\
\text { G, dan Emilia K }\end{array}$ & $\begin{array}{l}\text { Influnce Of Financial } \\
\text { Literacy On Management } \\
\text { Of Personal Finances In A } \\
\text { Young Household }\end{array}$ & $\begin{array}{l}\text { The importance of financial literacy to } \\
\text { management of personal finances in a } \\
\text { young household. Responsible } \\
\text { management of personal finances should } \\
\text { be fostered since early stages of life, as } \\
\text { financial mistakes made during the years } \\
\text { of youth can be costly and difficult to } \\
\text { correct in the future. }\end{array}$ \\
\hline Paidi & $\begin{array}{lcr}\text { Strategi } & \text { Persiapan } & \text { Masa } \\
\text { Pensiun } & \text { Bagi } & \text { Para } \\
\text { Karyawan. } & & \end{array}$ & $\begin{array}{l}\text { 4(empat) strategi yang harus dipersiapan } \\
\text { untuk menghadapi masa pensiun yaitu } \\
\text { melalui proyeksi tabungan dan investasi } \\
\text {,memelihara silaturahim, menjaga pola } \\
\text { hidup yang sehat dan melakukan kegiatan } \\
\text { keagamaan. }\end{array}$ \\
\hline
\end{tabular}




\section{HASIL DAN PEMBAHASAN}

Kecemasan yang terjadi oleh sebahagian besar pekerja dalam menghadapi purnabakti tentulah beralasan, karena purnabakti dapat diibaratkan sebagai transisi jalan kehidupan manusia yang melibatkan perubahan lingkungan sehingga dapat mempengaruhi ataupun mengubah kebiasaan hidup. Kebiasaan hidup dapat berupa dalam kesehatan jasmani maupun rohani, berinteraksi sosial dan lingkungan, tekanan psikologis dan sekaligus mengubah identitas maupun pilihan-pilhan hidup lainnya. Dengan kata lain bisa dianggap sebagai perpindahan dari fase bekerja menjadi tidak bekerja dengan memiliki segudang perubahan yang menyertainya

Guna menghadapi kecemasan tersebut terutama dalam hal perencanaan keuangan, beberapa penulis yang menyarankan untuk untuk mempersiapkan sejak dini, terutama di saat seseorang memasuki usia produktif.

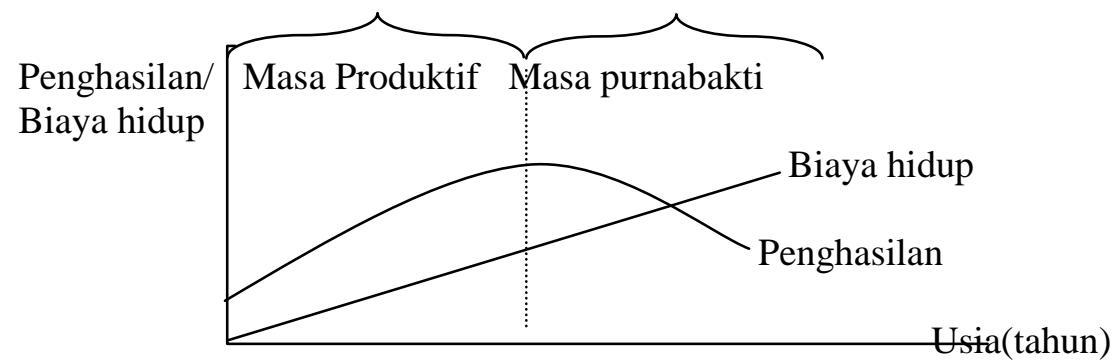

Gambar 1. Hubungan penghasilan/biaya hidup di masa produktif dan di masa purnabakti Sumber:Sundjaja,2015:503

Dalam gambar di atas dijelaskan bahwa ketika memasuki masa produktif, penghasilan seseorang akan mengalami peningkatan sejalan dengan biaya kehidupan. Akan tetapi, ketika memasuki usia purnabakti atau pensiun, penghasilan seseorang cenderung menurun, sedangkan biaya hidup terus meningkat karena perubahan inflasi dan juga munculnya pengeluaran yang tidak direncanakan, kesehatan yang mulai menurun ataupun perubahan-perubahan lainnya. Atas dasar pemahaman tersebut di atas, penulis berargumen perlu kiranya dibahas keterkaitan antara perencanaan keuangan dengan siklus hidup manusia.

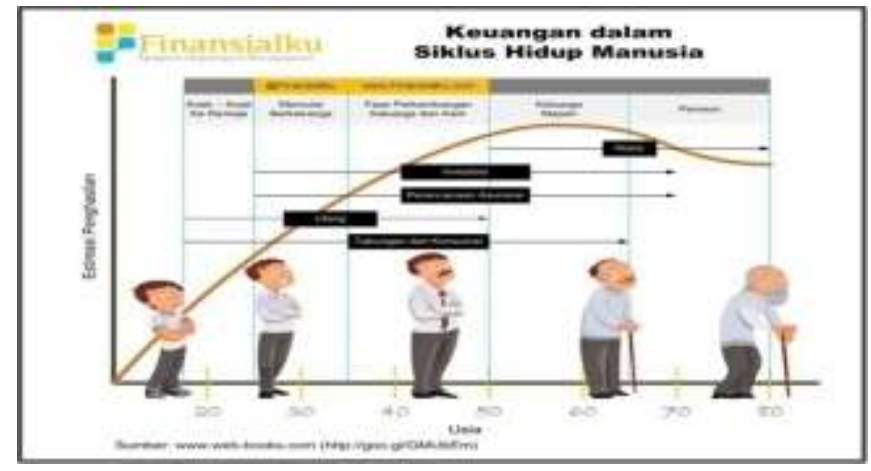

Gambar 2: Keuangan dalam siklus kehidupan manusia

Sumber: www.Web-book.com (http://goo.gl/GMUbEm)

Dimulai pada usia remaja yaitu berkisar di atas 20 (duapuluh) tahun atau lebih dikenal dengan masa muda, beberapa orang memprediksikan merupakan masa tanpa beban dan meyenangkan. Rata-rata berpendidikan setingkat SLTA/SMK ataupun sedang kuliah. Di usia tersebut pada umumnya mereka telah mengenal bagaimana uang, tabungan, utang, ataupun 
kartu kredit. Jika di Eropa di usia tersebut terutama di atas usia 17(tujuhbelas) tahun mereka harus sudah bisa mengatur segala aspek kehidupannya termasuk dalam hal keuangan. Sementara di Indonesia dalam aspek keuangan sampai saat ini masih sulit diterapkan, apalagi bagi mereka yang masih dibiayai oleh orang tua ataupun yang lebih mengutamakan pada pendidikan. Namun demikian, sejalan dengan perkembangan zaman dan dengan bertambahnya jumlah penduduk berdasarkan Peraturan Menteri Pendidikan dan Kebudayaan Republik Indonesia No.70 Tahun 2013 untuk kewirausahaan masuk kelompok wajib dalam kurikulum sebagai mata pelajaran pendidikan menengah. Diharapkan mereka kelak memperoleh gambaran membekalkan diri dengan usaha mandiri tanpa harus ketergantungan dengan bekerja pada perusahaan pemerintah maupun perusahaan swasta.

Tahap selanjutnya usia setelah lulus pendidikan SMA/SMK atau lulus S1. Di usia ini, mayoritas orang sedang atau baru memulai untuk mencari pekerjaan ataupun mencoba membangun bisnis. Di usia inilah menurut banyak penulis sebagai awal perjalanan dalam mempersiapkan masa depan dan juga masa tua atau masa purnabakti.

Tahap selanjutnya di usia 35 (tiga puluh lima) tahun s/d diusia 50 (lima puluh)an, merupakan usia masa proteksi ataupun akumulasi kekayaan karena berada di masanya karir mulai ataupun sudah menanjak. Pada masa-masa ini orang sudah merencanakan kehidupan masa depan dan sudah mulai merencanakan ataupun melakukan investasi, proteksi jiwa, dan lain-lain.

Pada usia 50 (limapuluh) tahun s/d 55 (lima puluh lima) tahun orang berada di masa prapensiun (pre-retirement). Menurut psikolog maupun peneliti, sebaiknya pada fase ini orangorang sudah memiliki kekayaan yang baik dan harus memikirkan distribusi kekayaannya maupun warisannya kelak.

Fase yang terakhir atau masa purnabakti, orang-orang akan cenderung menggunakan kekayaan yang sudah disiapkan pada fase-fase sebelumnya. Dimasa ini sebaiknya adalah merupakan masa-masa menikmati hidup, bersantai ria ataupun mengisi hidup dengan yang bermanfaat untuk diri sendiri, keluarga maupun sosialisasi dengan cara ikut kegiatan sosial dengan lingkungan tempat tinggal ataupun lebih fokus untuk keagamaan, bercengkerama dengan keluarga, dan lain-lain.

Berdasarkan pengamatan, cukup banyak orang yang telah memiliki kesadaran dalam mempersiapkan masa purnabaktinya. Namun demikian, dalam pelaksanaannya masih banyak yang belum sepenuhnya memahami bahwa perlunya perencanaan keuangan sebagai usaha yang bertujuan untuk mencapai kebebasan finansial di masa tua. Banyak yang hanya mengandalkan program purnabakti dari perusahaan atau instansi tempat mereka bekerja, sementara tidak semua perusahaan ataupun instansi yang memberikan dana pensiun seluruhnya disaat memasuki usia purnabakti. Kalaupun ada, masih banyak para prapurnabakti yang tidak tau ataupun tidak mau tau atau juga ada yang bingung dalam mengelola dana pensiun untuk kehidupan selanjutnya.

Berdasarkan seluruh pembekalan yang diterima para peserta serta hasil diskusi kelompok maupun kesimpulan dari para peserta pelatihan para-purnabakti yang dibagi sebanyak 4(empat) kelompok didapatkan 6(enam) langkah yang perlu disiapkan dalam hal keuangan guna persiapan masa purnabakti, antara lain:

1. Mengatur kembali keuangan

Menyelaraskan penghasilan, pengeluaran dan cadangan, yaitu dengan cara mengalokasikan sumber mana saja yang merupakan sumber penghasilan, selanjutnya dialokasikan pada pengeluaran-pengeluaran apa saja yang dibutuhkan serta seberapa besar dana yang harus dicadangkan. Untuk keuangan yang perlu dirinci sesuai dengan petunjuk instrumen pembekalan saat itu adalah untuk sebulan maupun tahunan. Dalam penelitian ini, mayoritas peserta semuanya merahasiakan dan tidak terbuka tentang pengaturan maupun nilai riil estimasi anggaran rumah tangga masing-masing karena memang penghasilan yang diperoleh mereka masing-masing berbeda dan juga kebutuhan pokok ataupun kebutuhan lain mereka satu sama 
lain juga berbeda besarannya. Terlepas dari kesemua di atas dan guna tidak terjadi kesalahan menurut Meydian dkk(Detik Finance) hendaknya para purnabakti dapat meluangkan waktunya untuk membaca beberapa artikel tentang keuangan karena dengan membaca artikel-artikel tersebut setidaknya dapat menambah pengetahuan dan membuka wawasan tentang keuangan, memberikan panduan praktis dalam perencanaan keuangan dan membantu mengambil keputusan dalam hal keuangan.

2. Membuat konsep dana cadangan untuk darurat dengan tidak membelanjakan semua penghasilan yang diperoleh.

Memiliki dana cadangan dimaksudkan untuk mengurangi sifat konsumtif, mengamati pergerakan keuangan, mencari sumber dana lain selain dana utama (https://www.carajadikaya.com/tips-memiliki-dana-cadangan/). Sebagai contoh, A bekerja dan mendapatkan penghasilan (berupa gaji) sebesar Rp.5.000.000,- ( lima juta rupiah ) perbulan, dan memiliki pengeluaran sebesar Rp4.500.000,- ( empat juta limaratus ribu rupiah) perbulan, maka A membutuhkan jumlah dana cadangan sebesar 3 bulan s/d 6 bulan pengeluarannya. Ini berarti, A harus memiliki dana cadangan sebesar Rp 13.500.000,- (tigabelas juta limaratus ribu rupiah) s/d Rp.27.000.000, (duapuluh tujuh juta rupiah) dalam rekening A, sebagai persediaan apabila A harus mengalami kehilangan penghasilan. Tetapi, bila penghasilan yang A dapatkan tidak stabil, seperti komisi yang jumlahnya tidak tetap, maka jumlah dana cadangan sebaiknya adalah sebesar 12 (duabelas) bulan pengeluaran bulanan. Ini berarti, bila pengeluaran A mencapai Rp 4.500.000,- (empatjuta limaratus ribu rupiah) per bulan, maka A harus memiliki dana cadangan sebesar Rp 54.000.000,- (limapuluh empat juta rupiah) dalam rekening. Intinya, semakin besar risiko tidak berpenghasilan dalam pekerjaan seseorang, semakin besar juga jumlah dana cadangan yang sebaiknya dimiliki.

3. Meninjau kembali dan bila perlu kendalikan hutang-hutang.

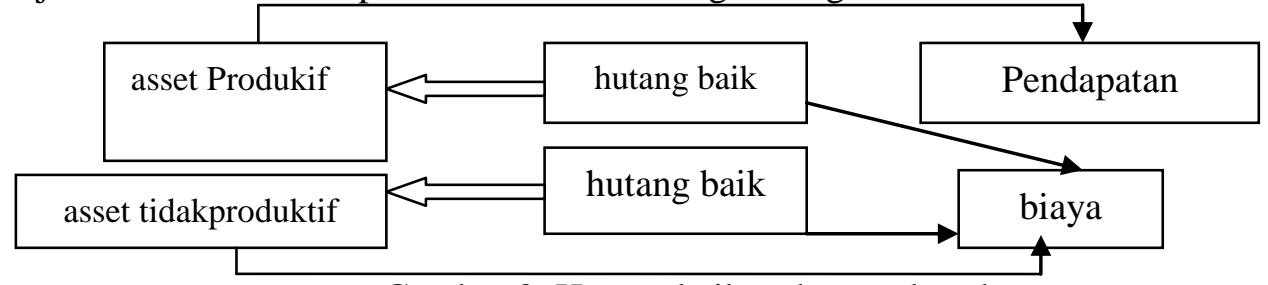

Gambar 3: Hutang baik vs hutang buruk

Sumber : Data olahan

Memilah milih yang manakah hutang baik dan manakah hutang yang buruk, atau bila perlu hindari berhutang dalam bentuk apapun. Seandainya memang memerlukan dana cepat cair ataupun bersifat penting sekali, misalnya, untuk modal usaha, umumnya para peserta dalam pembekalan ini telah dipasilitasi dengan bergabung ke dalam koperasi perusahaan dengan beberapa persyaratan yang tidak memberatkan.

4. Membeli asuransi

Inti dari pembelian asuransi menurut sebagian peserta yang telah memiliki asuransi dimaksudkan untuk mengalihkan resiko keuangannya pada asuransi. Banyak jenis asuransi yang telah dijalankan oleh para peserta, seperti asuransi kesehatan, yaitu dalam bentuk asuransi prodential, asuransi kendaraan dan lain-lain. Berdasarkan tanya jawab kebanyakan dari para peserta lebih dominan membeli asuransi dikesehatan. Bagi mereka asuransi merupakan salah satu cara yang terbaik dalam rangka mempersiapkan kehidupan yang lebih baik di masa depan terutama ketika pensiun.

\section{Berinvestasi}

Investasi dapat diartikan sebagai kegiatan menempatkan uang atau dana pada sebuah instrumen keuangan dengan harapan dapat memberikan keuntungan atau tambahan penghasilan tertentu atas dana tersebut di masa yang akan datang. Penghasilan besar bukan segalanya, banyak orang yang berpenghasilan besar tetapi mereka tidak memiliki apa-apa. Uangnya habis 
untuk memenuhi kebutuhan hidup dan memenuhi gaya hidupnya yang mahal. Oleh karena itu, perlu kiranya melakukan investasi agar dana pensiun tidak habis dengan percuma. Dalam investasi harus dimulai dari adanya sebuah rencana atau tujuan keuangan yang ingin dicapai di masa yang akan datang, baik untuk tujuan rencana jangka pendek ,jangka menengah maupun jangka panjang. Berdasarkan wawancara diperoleh hampir 85\% dari 14 pasangan sebagai peserta pelatihan rata-rata telah memiliki investasi dalam bentuk harta tetap maupun tidak tetap bahkan sampai saat ini investasi tersebut telah memberikan penghasilan tambahan. Sebahagian dari mereka juga tertarik untuk berinvestasi dalam pengelolaan berternak burung puyuh sebagaimana pembekalan yang diterima berdasarkan peninjauan langsung ke tempat lokasi, yaitu di Sukabumi dan pemaparan langsung dari pemilik usaha, yaitu Bpk. Slamet Woeryadi SP,MP.

\section{Berwirausaha}

Dimaksudkan untuk menambah nilai ekonomi di masa purnabakti, dengan catatan usaha yang dipilih tidaklah beresiko tinggi terutama dalam berpikir, tidak membutuhkan banyak waktu dan tenaga, mudah dioperasikan dan terutama usaha yang dipilih sesuai dengan hobby ataupun keahlian yang menjadi nilai tambah. Intinya untuk berwirausaha di masa purnabakti haruslah dilakukan survey, menangkap peluang usaha, mulai dari modal kecil, anggaran yang sederhana termasuk penggunaan promosi murah dan meriah, sesuai dengan hoby, yang kesemuanya dipertimbangkan dengan faktor fisik, kesehatan, dan sebagainya.

Berdasarkan hasil survey dan wawancara terhadap peserta pelatihan diperoleh data hanya $60 \%$ dari total peserta pelatihan yang telah memiliki usaha yang dilakukan sejak muda ataupun baru beberapa tahun dijalankan. Di antara mereka, jenis usahanya bergerak di bidang properti, rental, membuka kursus dan lain-lain. Umumnya usaha mereka sampai saat ini terus berjalan dan mengalami peningkatan adalah properti karena jenis usaha ini tidaklah membutuhkan banyak tenaga sekalipun diawalnya membutuhkan biaya yang cukup besar. Usaha properti mereka berada ditempat yang benar-benar strategis seperti di dekat sekolah, dekat pabrik, pasar dan tempat ramai lainnya. Sebagian dari peserta juga meluangkan waktu dengan meyewakan atau rental mobil maupun motornya kepada pengendara yang tergabung dalam gojek dan grab.

\section{SIMPULAN DAN SARAN}

Perencanaan keuangan dan siklus hidup manusia memiliki kaitan yang erat. Dari siklus kehidupan manusa memiliki fase kehidupannya terutama menjelang usia remaja yaitu diatas usia 20 tahun, dimana umumnya mereka sudah mulai lebih bijak dengan keuangan yang diperoleh baik dari orang tuanya maupun dari kerja kerasnya, dengan demikian mereka memerlukan perencanaan keuangan agar tetap sejahtera dan dapat memenuhi tujuan keuangan, khususnya tujuan jangka menengah dan jangka panjang.

Dalam persiapan keuangan menghadapi masa purnabakti tidak selalu dari kemauan ataupun keterampilan dalam berwirausaha apalagi bagi mereka yang baru memulainya ketika mendekati masa pensiun, namum juga ada beberapa lainnya yang tidak kalah penting yaitu mengatur kembali keuangannya, membuat konsep dana cadangan dengan tidak membelanjakan semua penghasilan yang diperoleh, meninjau kembali bila perlu kendalikan hutang-hutang, membeli asuransi dan berinvestasi

Dalam hal mengatur kembali keuangan terutama dalam anggaran rumah tangga, mayoritas orang-orang akan merahasikan atau tidak terbuka kepada orang lain yang tidak dipercayanya, namum demikian membuat anggaran seluruh penghasilan atau pendapatan, pengeluaran dan cadangan tetap harus dikerjakan agar keuangan sejahtera dimasa purnabakti. 
Dana pensiun yang didapat jika tidak dikelola dengan baik akan habis dengan cepat, perubahan gaya hidup tidaklah sama ketika saat masih bekerja, oleh karenanya sebaiknya dipergunakan seefektif dan seefisien mungkin, misalnya dengan berinvestasi ataupun berbisnis agar dapat berdaya guna.

Berinvestasi hendaknya berdasarkan pilihan sesuai dengan tujuan keuangan, kenali resikonya termasuk resiko profit resiko keluarga. janganlah tertipu dengan banyaknya kepemilikan kartu kredit, karena kartu kredit bukanlah uang tambahan, melainkan merupakan utang tambahan yang harus dilunasi.

Melakukan aktivitas dimasa purnabakti diperlukan, seperti halnya berwirausaha, yang perlu diperhatikan adalah bisnis tersebut sesuai hoby, tidak memerlukan waktu dan tenaga yang lama terutama dalam hal berfikir, sesuaikan dengan kondisi fisik serta kesehatan dan sebagainya.

Hal yang paling mendasar dari seorang pekerja dalam hal purnabakti adalah mengubah mindset dari seseorang yang berpenghasilan tetap menjadi seseorang yang memiliki keyakinan akan peluang untuk memperoleh rezeki atau penghasilan yang justru jauh lebih besar. Janganlah terlena dengan pendapatan ataupun kehidupan yang dijalani tapi pikirkan bagaimana kelak jika sudah tidak bekerja atau dimasa purnabakti.

Harta yang paling berharga selain keluarga adalah waktu, dimana disaat seseorang aktif bekerja sebagai pekerja maka waktu yang dimilikinya, pada umumnya ditukarkan dalam bentuk gaji yaitu uang. Buatlah prinsip bagaimana penghasilan mengejar kita dan bukan sebaliknya. Uang memang dibutuhkan tapi bukanlah segalanya oleh karenanya janganlah meremehkan masa purnabakti, persiapan dari dini guna menghadapi masa purnabakti.

\section{DAFTAR RUJUKAN}

Rusmardiana, A., (2016). Komitmen PT. GMF AeroAsia Terhadap Karyawan Pra-Purnabakti Melalui Pembekalan. SOSIO-E-KONS, Vol. 8 No. 3, Desember 2016. hal. 202-209

Didin, H., \& Tanjung, H..(2015). Manajemen Syariah Dalam Praktik. Jakarta:Gema Insani.

Martono.(2016). Bank dan Lembaga Keuangan Lain. Cetakan ke 3.Yogyakarta: Ekonisia.

Meydian Eka Rini, Aidil Akbar Madjid dan Partners. Pentingnya Membaca Artikel Keuangan. Detik Finance. Selasa, 13 Feb 2018.

Navickas M, Tadas G, dan Emilia K.2015. Influnce Of Financial Literacy On Management Of Personal Finances In A Young Household. Verslas: Teorija ir prakTika / Business: Theory and pracTice, ISSN. 1648-0627 / ELSSN 1822-4202 http://www.btp.vgtu.lt .hal $32-40$.

Paidi.(2014).Strategi Persiapan Masa Pensiun Bagi Para Karyawan. Skripsi. STIE Dharma Bumiputera Jakarta.

Peraturan Menteri Pendidikan Dan Kebudayaan Republik Indonesia No.70 Tahun 2013. Kerangka Dasar Dan Struktur Kurikulum Sekolah Menengah Kejuruan/Madrasah Aliyah Kejuruan. Hal 12

Prasetyono, H. (2016). Graduate Program Evaluation in the Area Leading Educational, Outlying and Backward. Journal of Education and Practice, ISSN 2222-1735 (Paper) ISSN 2222-288X (Online), 7, (36), 2016, pp. 109-115.

Santrock, John, W. (2015). Life Span Development: Perkembangan Masa Hidup. Edisi lima belas 5. jilid 2. Jakarta: Erlangga

Sundjaja, R.S., \& Barlian, I. (2015). Manajemen Keuangan 1. Edisi kesembilan. Jakarta: Literata Lintas Media

Smith, J. (2017). Psikologi Kualitatif Panduan Praktis Metode Riset.Yogyakarta: Pustaka Pelajar 


\section{Sosio e-kons}

Volume 11, No. 1, April 2019, pp. 28-36

e-ISSN: 2502-5449

p-ISSN: 2085-2266

DOI : 10.30998/sosioekons.v11i1.2561

https://id.wikipedia.org/wiki/Pensiun, diunduh 04 Pebruari 2018 jam 20.00

http://www.fpsbindonesia.net/index.php?menu=publikmedia\#definisi), diunduh 04-02-2018 jam 20.30

https://www.carajadikaya.com/tips-memiliki-dana-cadangan . diunduh Januari 2019 jam 7.30 